\title{
Canonical Shape Analysis of Hausa and Bole Ideophones
}

\author{
Almustapha Wali Sambo * \\ (Sokoto State University, Nigeria)
}

\begin{abstract}
Hausa and Bole are two languages from the same phylum i.e. Afro-asiatic. They have some common various linguistic features, most especially phonological and syntactic features. The main purpose of this paper is to come up with one of the phonological aspects of one of the word classes of Hausa and Bole. This means, we will analyse the syllable structure, which is canonical shape of ideophones of both languages using descriptive method of analysis adopted by Newman (2000). In Hausa, likewise in Bole, ideophones are numerous and several of them are commonly used syntactically. But, we will not deal with their syntactical use or function in this paper, what we focus on, is just their canonical shapes i.e. syllable structures. The paper is divided into four sections: sections one and four are introduction and conclusion respectively, while section two is descriptive analysis of canonical shape of Hausa ideophones, and section three, is of Bole ideophones.
\end{abstract}

Keywords: Hausa, Bole, ideophone, syllable structure, tone patter

\section{Introduction}

Hausa is a major language of West Africa with an estimated 35-40 million speakers (Newman \& Newman, 2001:264). According to Ethnologue estimation, Hausa speakers are 41 million $(26,929,000$ as first language (L1) speakers, while $15,000,000$ as second language (L2) speakers). Hausa is the first language of ethnic Hausas and some settled Fulanis in Hausaland, which stretches across the northern states of Nigeria and into southern Niger, and of some Hausa communities in the Sudan. It is also spoken as a first language by scattered settlements (zango) throughout West Africa, and as a second language or lingua franca ${ }^{(1)}$ by millions of non-Hausas in northern Nigeria and in some

\footnotetext{
* Almustapha Wali Sambo: (1)Department of Nigerian Languages, Faculty of Arts and Islamic Studies, Sokoto State University, Sokoto, Nigeria. (2)Department of Linguistics and Foreign Languages, Faculty of Arts and Islamic Studies, Bayero University, Kano. E-mail: mustaphaoldman@gmail.com.

(1) Lingua franca is a language systematically used to make communication possible between people who do not share a native language, in particular when it is a third language, distinct from both native languages (Chirikba, 2008:31). It is also known as a bridge language, common language, trade language or vehicular language.
} 
parts of Benin Republic, Burkina Faso, Cameroon, Chad, Cote d'Ivoire, Ghana, Mali and Togo. It is one of the official national languages of Nigeria ${ }^{\circledR}$. Hausa belongs to Chadic language family and is the largest member of the family. It is described by Ethnologue as A.1 language (along with Gwandara language) among West-Chadic languages. This means, in turn, Hausa belongs to Afro-Asiatic phylum.

Bole, according to Schuh and Gimba (2015), "is a language spoken in Yobe and Gombe states of northern Nigeria. About 25,000-30,000 people speak Bole, making it one of the widely spoken languages in the region, perhaps surpassed only by its linguistics cousin Hausa, dominant language of all northern Nigeria and the sub-saharan language with the largest native speakers and Kanuri, historically dominant language of Northern Nigeria over the past few centuries. Bole is a member of the Chadic family along with Hausa. Bole is a member of the West branch of Chadic, but Bole and Hausa are not particularly closely related." Ethnologue described it as A.2 language among West-Chadic languages. This indicates that both Bole and Hausa are from the same language family which is Afro-Asiatic.

The two languages share a number of typological features such as similar consonant inventories. They are both tonal languages with three surface tones: High $(\mathrm{H})$ tone which is notationally left unmarked /a/, Low (L) tone indicated by a grave accent /à/, and Falling (F) tone indicated by a circumflex /â/. Some Hausa researchers (Newman, 1992; Yalwa, 2002; Sambo, 2014) pointed out that "evidence from a number of areas, such as contractions, paradigmatic patterns, morphological formations, etc., shows clearly that the falling tone represents $\mathrm{H}+\mathrm{L}$ on a single syllable, where, moreover, the level tones originally belonged to two separate syllables" (Newman, 1992:128). Examples: kadà > kâr 'don't', zaa nì > zân 'I will'. Both languages also have short and long vowels. Long vowels could be indicated by double letters /aa/ (tone is marked on first vowel only /àa/), or by putting a diacritic called "macron" on top of short vowel /ā/, or by assigning colon in front of a short vowel /a:/. Below are some examples of Hausa and Bole words along with their tone pattern and vowel length:

Examples:

$\begin{array}{llll}\underline{\text { Hausa }} & & \underline{\text { Bole }} \\ \text { (1) } \text { kama }=\text { /ka:mà:/ } & \text { 'to catch' } & \text { soba }=/ \mathbf{s o : b a ̀ / ~} & \text { 'friend' } \\ \text { (2) } \text { yara }=\text { /jâraa/ } & \text { 'boys' } & \text { kom }=/ \mathbf{k o ̂ m} / & \text { 'cow' } \\ \text { (3) } \text { reras }=\text { /rèras/ } & \text { 'be well lined up' } & \text { shororo }=/ \text { /ò̀rò̀rò } / 2 & \text { 'watery' }\end{array}$

\footnotetext{
(1) Along with Igbo and Yoruba languages.

(2) From this example (1), we used all the notational methods of indicating vowel lengthening, but we will use, entirely in this paper, the notation of doubling (aa) in order to indicate long vowel.
} 


\section{Canonical shapes of Hausa and Bole ideophones}

Ideophones are special class of words that are used to describe sound, colour, shape, manner, etc. According to Newman (2000:242), ideophones are 'phonaesthetic words' that "describe sound, colour, smell, manner, appearance, state, action or intensity...that is they are words that are vivid vocal images or representation of visual, auditory and other sensory or mental experience". Crystal (2008:235) on the other hand defines ideophone as "a term used in linguistics and phonetics for any vivid representation of an idea in sound, such as occurs through onomatopoeia". Ideophones are characterized not only by their expressiveness in meaning, but also by their form. Ideophones in Hausa and Bole have a much more significant role than do in English onomatopoeic words.

Ideophones can be grouped into regular phonological classes. In this section, we descriptively analyse some of Hausa and Bole ideophones based on their common form, that is their syllable structures or 'canonical shapes' as stated by Newman (2000).

\subsection{Analysis of Hausa Ideophones canonical shape}

In Hausa, ideophones are numerous and several of them are very commonly used. Most ideophones in Hausa tend to be the same syllable structure end in a consonant. Since ideophones are extremely numerous in Hausa, we have only been possible to identify the following canonical shapes with few examples of ideophones.

\subsubsection{Monosyllabic}

Monosyllabic ideophones contain only one syllable which has the Onset + Nucleus + (Coda) structure, whereas Onset stands for Consonant, Nucleus stands for Vowel (short or long), and optional Coda stands for Consonant or semi-vowel (approximant sound). The following are identified shapes of monosyllabic ideophones in Hausa:

\section{(i) $\underline{\mathrm{CVC}}$}

This shape is for monosyllabic ideophones typically consist of Consonant-Vowel (short)Consonant closed syllable (including $\mathrm{CV}_{\mathrm{y}}$ and $\mathrm{CV}_{\mathrm{w}}$ ideophones having approximants as their final (coda) sounds). These ideophones most commonly have $\mathrm{H}$ tone. A lesser number have $\mathrm{L}$ or $\mathrm{F}$ tone. Examples:

High Tone
(4) $k \mathbf{a f}=/ \mathbf{k a} \phi / \quad$ 'emphasizes stealing all'
CVC
(5) shar $=/ \int \mathrm{ar} / \quad$ 'emphasizes greenness or freshness'
CVC
(6) $\boldsymbol{f a u}=/ \boldsymbol{\phi a w} / \quad$ 'emphasizes extremeness of thing' 


\section{Almustapha Wali Sambo}

CVC

Low Tone

(7) $\operatorname{dim}=/$ dìm/ 'of large volume'

CVC

(8) gum = /gùm/ 'emphasizes unpleasant odor'

$\mathrm{CVC}$

(9) $\boldsymbol{w u l}=/$ wùl/ $\quad$ 'pass by very quickly'

CVC

Falling Tone

(10) cir $=/ \mathrm{ffî} \mathrm{r} / \quad$ 'sound made to drive away birds or children'

$\mathrm{CVC}$

(11) bif = /bî $\Phi / \quad$ 'sound of heavy object falling'

$\mathrm{CVC}$

(12) $\operatorname{dim}=/$ dîm/

'sound of hitting with a thud'

CVC

There is also a few monosyllabic ideophones with the shape CVV (Consonant-Vowel (long)). All of these ideophones with such structure describe some kind of movement or sound. Below are the complete examples of these ideophones, according to Newman (2000). And, they all, except one, have low tone.

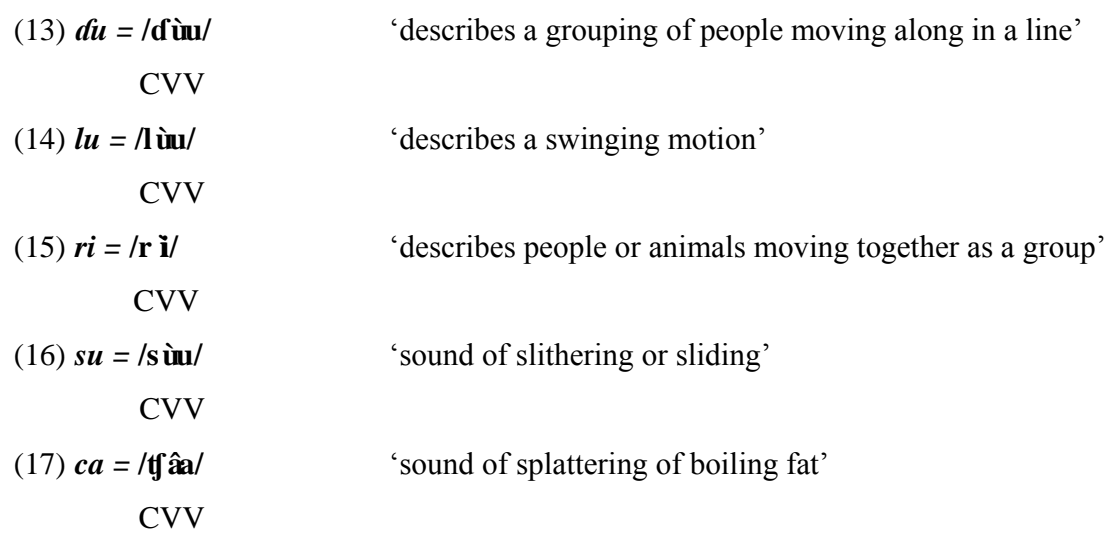

\subsubsection{Disyllabic}

Disyllabic ideophones are typically ideophonic words consisting of two syllables. First and second syllables could be iambic light-heavy or closed heavy-heavy or open-closed heavy-heavy respectively ${ }^{(1)}$. The following are available canonical shapes of Hausa

(1) “A light (or 'weak') syllable is one whose rhyme comprises a short-vowel nucleus alone or followed by 
disyllabic ideophones:

\section{(i) $\underline{\text { CV-CVC }}$}

In this disyllabic shape of ideophones, the first vowel is always short /i, $\mathbf{a}, \mathbf{u} /$, and the two vowels (of first and second syllables) are identical ${ }^{\mathbb{D}}$. They have iambic (light-heavy) pattern. Four tone patterns occur in this disyllabic consonant-final, which are: $\mathrm{H}-\mathrm{H}$ (the most common), L-L, H-L, and L-H. Examples:

High-High Tone Pattern

(18) sumul $=/$ su.mul $/ \quad$ 'clean'

$\mathrm{CV}-\mathrm{CVC}$

(19) $\mathbf{k}$ ukut $=/ \mathbf{k}$ 'u.k'ut $/ \quad$ 'emphasizes closeness of relationship'

CV-CVC

(20) fatau $=/$ a.taw $/ \quad$ 'emphasizes greenness'

$\mathrm{CV}-\mathrm{CVC}$

Low-Low Tone Pattern

(21) gunus = /gù.nùs/ 'describes an outburst of stench'

CV-CVC

(22) shirim $=/$ Ji.rìm $/ \quad$ 'shady'

$\mathrm{CV}-\mathrm{CVC}$

High-Low Tone Pattern

(23) riris $=$ /ri.rìs/ 'indicates intensity of crying'

$\mathrm{CV}-\mathrm{CVC}$

(24) $\boldsymbol{k}$ watsam $=/ \mathbf{k}^{\mathrm{w}} \mathbf{a}$ a.s'àm/ 'suddenly'

$\mathrm{CV}-\mathrm{CVC}$

Low-High Tone Pattern

(25) galau $=$ /gà.law $/ \quad$ 'with mouth wide open'

$\mathrm{CV}-\mathrm{CVC}$

(26) jugum $=/$ dłù.gum/ 'being sad, dejected, despondent'

$\mathrm{CV}-\mathrm{CVC}$

(ii) $\underline{\mathbf{C V}} \underline{\underline{C}-\mathbf{C V}} \underline{\underline{\mathbf{C}}}$

This class is similar to the preceding in being composed of consonant-final, disyllabic

a coda of no more than one short consonant (in terms of phonological length, a mora); a heavy (or 'strong') syllable is any other type (its phonological length being greater than one mora)" (Crystal, 2008: 520). Open refers to a syllable which ends in a vowel, as opposed to the closed which refers to syllable which ends in a consonant.

(1) That is, they have same phonetic features. 


\section{Almustapha Wali Sambo}

ideophones with identical vowels. It differs in having a closed heavy initial syllable. The tone pattern is Low-High. Examples:
(27) birjik = /bìr.dzik/
'in large number scattered abundantly'
$\mathrm{CV}_{\mathrm{i}} \mathrm{C}-\mathrm{CV}_{\mathrm{i}} \mathrm{C}$
(28) kirtif = /kìr.tiф/
'describes thickness of a fluid or liquid'
$\mathrm{CV}_{\mathrm{i}} \mathrm{C}-\mathrm{CV}_{\mathrm{i}} \mathrm{C}$
(29) karkaf = /k'àr.k’a $\phi /$
'completely, being used'
$\mathrm{CV}_{\mathrm{i}} \mathrm{C}-\mathrm{CV}_{\mathrm{i}} \mathrm{C}$

\section{(iii) CVV-CVC}

There is small set of disyllabic consonant-final ideophones that is prosodically similar to the preceding class (ii) in having an initial heavy syllable and Low-High tone pattern (and one example of Low-Low). In this shape, the initial syllable is open and the two vowels are always different. Examples:
(30) fetal $=/$ фèe.tal/
'indicates openness of a space'
CVV-CVC
(31) jawur = /dłàa.wur/
'bright red'
CVV-CVC
(32) tatul = /tàa.tul/
'be full with a drink, overdrunk'
CVV-CVC
(33) Kikam $=/$ k'ìi.k’àm/
'motionless'
CVV-CVC

\subsubsection{Trisyllabic}

Trisyllabic ideophones refer to ideophonic words that typically contain three syllables. In Hausa, there are three classes of canonical shapes of trisyllabic ideophones, as we shall see below.

\section{(i) $\underline{\mathbf{C} \mathbf{V}_{\mathrm{i}}-\mathbf{C}_{\mathrm{J}}} \underline{\mathrm{V}}_{\mathrm{i}}-\mathrm{C}_{\mathrm{J}} \underline{\mathbf{V}_{\mathrm{i}}}$}

This group consists of monotonal trisyllabic ideophones containing identical short vowels and identical second and third consonants, i.e. the last two syllables are exact copies of one another. The vowels are either /a/ or /u/, never /i/. About two-thirds of the ideophones have all High tone; the others have all Low tone. Examples:

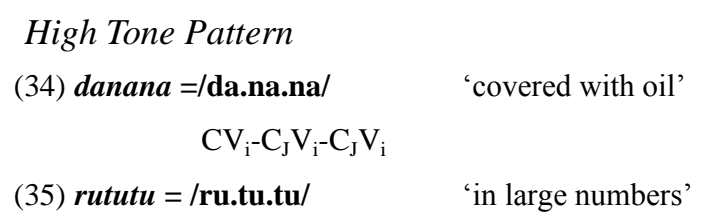




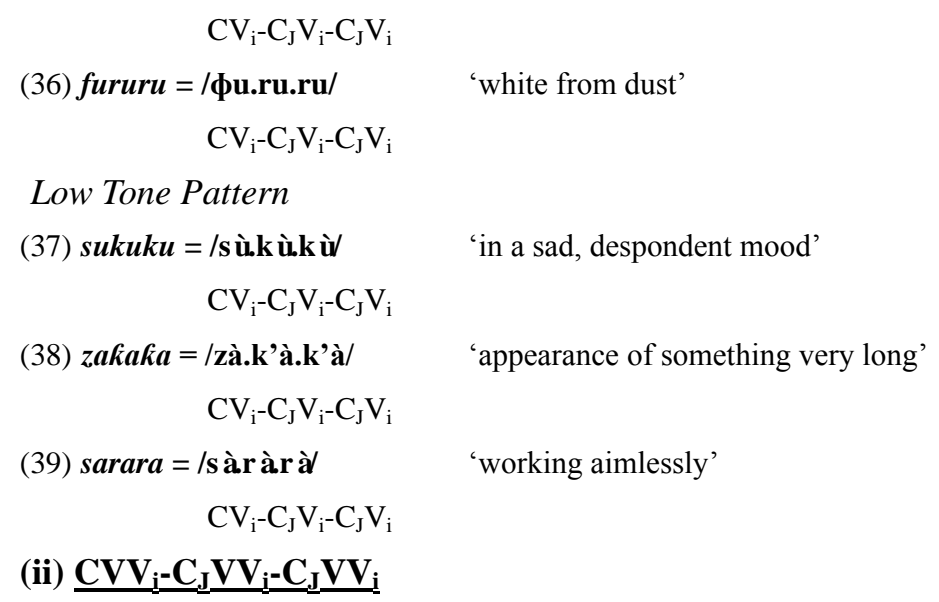

This is small class of trisyllabic ideophones, which is similar to the preceding group (i) in having identical vowels and matching second and third consonants. It is different in that the vowels are all long, typically most of them with the mid-vowels /e:/ and /o:/ (and one example with low vowel /a:/ according to Newman (2000:246)). The tone pattern is all Low. Examples:

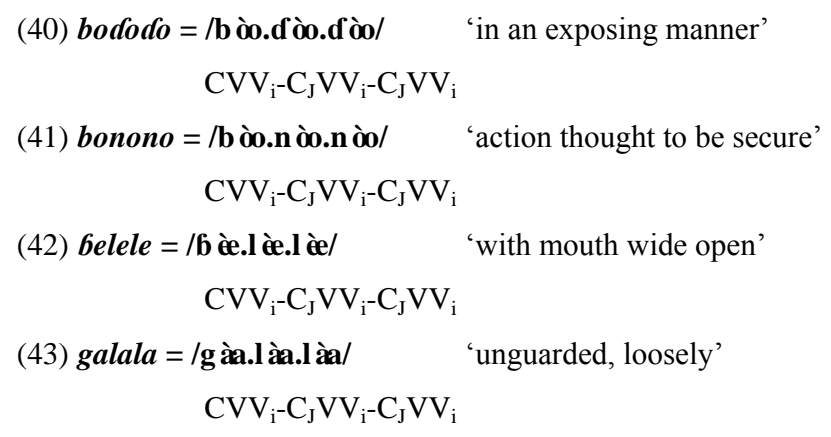

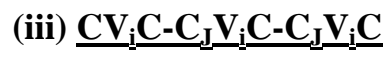

This class includes trisyllabic ideophones consisting of three closed syllables, the last two of which are identical, i.e. these ideophones are formed by reduplication of the final syllable of the usual disyllabic base. The vowels are all identical, but the consonants are distinct. They all have Low tone pattern. Examples:

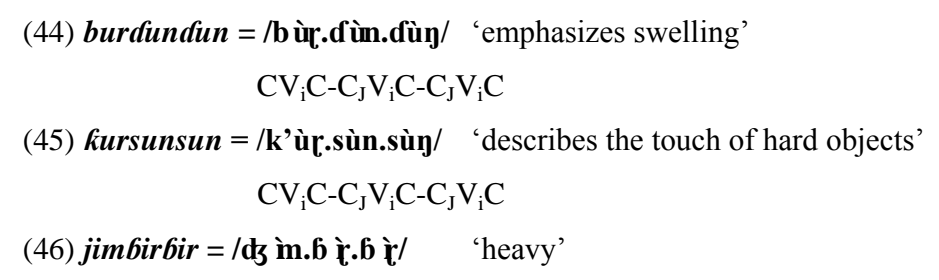




\section{$\mathrm{CV}_{\mathrm{i}} \mathrm{C}-\mathrm{C}_{\mathrm{J}} \mathrm{V}_{\mathrm{i}} \mathrm{C}-\mathrm{C}_{\mathrm{J}} \mathrm{V}_{\mathrm{i}} \mathrm{C}$}

\subsubsection{Polysyllabic}

In addition to canonical shapes that we have seen above, there are few exceptional shapes which do not fall into any one of the aforementioned ones. These ideophones are polysyllabic, i.e. they have more than one syllabic structure and their syllable structure is not identical to all of the structures or shapes that we have analysed. They all end in diphthong /ai/ or low vowel /a/ plus a nasal consonant. All of them have Low tone pattern. Newman (2000:249) gives the complete examples of these ideophones as we shall see below with their canonical shapes:

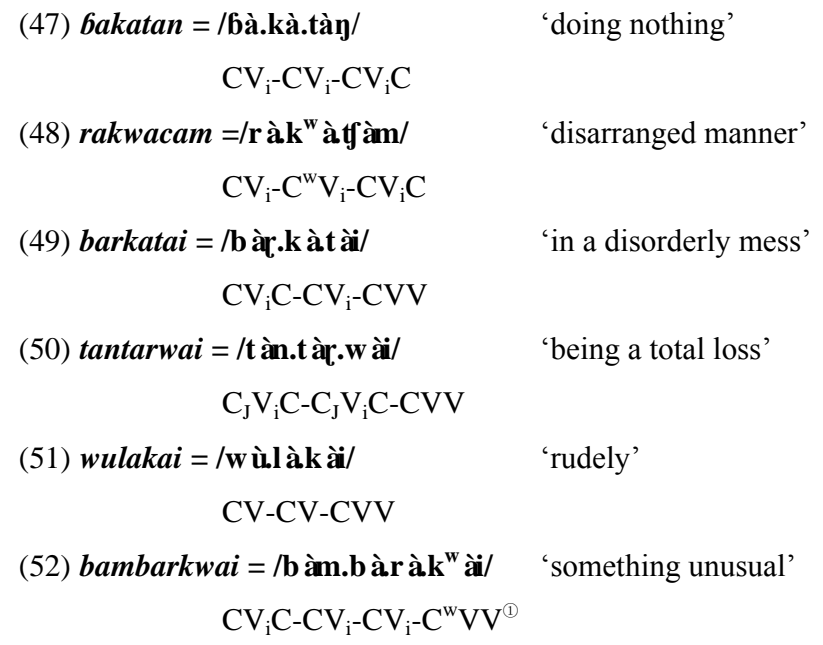

From the above examples 47-52, we noticed that the canonical shapes of the ideophones are different. Example 47 and 48 seem to be same, both have identical vowel in initial, second and third syllables; but the consonant of the second syllable in 48 is labialized, while in 47 the consonant of second syllable is not labialized, i.e. it is a primary articulation. Example 49 have identical vowel in first and second syllables, likewise in 50. But in 50, the first consonant of initial syllable is identical to first consonant of second syllable. Example 51 has its own shape which is not similar to any of the examples. Finally, example 52 has identical vowel in initial, second, and third syllables, plus a final labialized sound and a diphthong.

\footnotetext{
(1) Shapes like $\mathbf{C}^{\mathbf{w}}$ or $\mathbf{C}^{\mathbf{j}}$ refers to secondary articulation of a sound where a sound produced with two points of articulation. The above $\mathbf{C}^{\mathbf{w}}$ and $\mathbf{C}^{\mathbf{j}}$ are called 'labialization' and 'palatalization' respectively. Palatalization is a general term referring to any articulation involving a movement of the tongue towards the hard palate. Labialization is a general term referring to a secondary articulation involving any noticeable lip-rounding (Crystal, 2008).
} 


\subsubsection{Reduplicative}

In Hausa, there are some ideophones formed by reduplicating ideophonic base. Most of the reduplicative ideophones are having full reduplication of base plus an $\mathrm{H}-\mathrm{L}, \mathrm{H}-\mathrm{H}$, and $\mathrm{L}-\mathrm{H}$ tone melodies with the following canonical shapes.

\section{(i) $\underline{\mathrm{CV}} \underline{\mathrm{C}-\mathrm{CV}} \underline{\mathrm{C} \times 2}$}

In this shape of heavy-heavy syllable ideophones, the idephonic base is reduplicating two times in order to have reduplicative ideophones which have identical vowels in base and reduplicator plus two different tone melodies of H-L (i.e. High tone on base, while Low tone on reduplicator) and L-H (i.e. Low tone on base, while High tone on reduplicator. Examples:

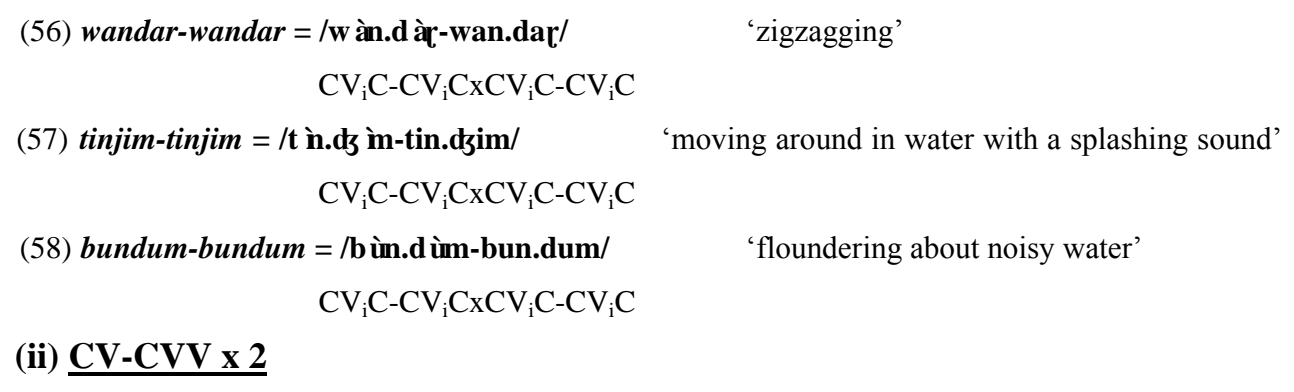

\section{(ii) $\underline{\mathrm{CV}-\mathrm{CVV} \times 2}$}

This shape of reduplicative ideophones has iambic (light-heavy) syllable structure in both base and reduplicator. The two vowels of first and second syllables are not identical (the first is short and the second is long). All base form syllables have High tone, while reduplicator syllables have Low tone. There is also some reduplicative ideophones that have similar canonical shape with this, but their tone melody is Low on base form and High tone melody on reduplicator. Examples:

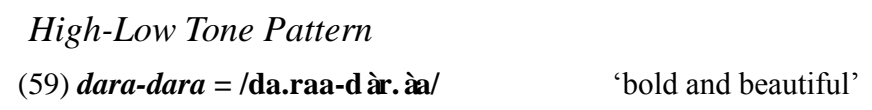




\section{Almustapha Wali Sambo}

(60) buzu-buzu = /bu.zuu-bù.zùu/ 'long unkempt hair'

CV-CVVxCV-CVV

(61) kiri-kiri $=/ \mathbf{k}^{\text {'i.rii-k'ì.rìi/ }}{ }^{1}$ 'openly'

CV-CVVxCV-CVV

Low-High Tone Pattern

(62) $c u k u-c u k u=/$ tyù.kùu-tfu.kuu/

'trying to get something in an underhanded way'

CV-CVVxCV-CVV

(63) faca-faca = /申à.tjàa- $\phi a . t j a a /$

'reckless spending or playing with water'

CV-CVVxCV-CVV

(64) wiki-wiki = /wì.k'ìi-wi.k'ii/

'fidgeting by children'

$\mathrm{CV}-\mathrm{CVV} \mathrm{xCV}-\mathrm{CVV}$

(iii) $\underline{C_{i}-C V_{i}} \underline{C} \times 2$

This shape of reduplicative ideophones also has iambic light-heavy syllable (but the heavy syllable in this shape is closed, unlike preceded shape (ii) that has second open heavy syllable), and identical vowels in both first and second syllables. But, this shape has two different tone melodies: H-L (High on base form, Low on reduplicator) and L-H (Low on base and High on reduplicator). Examples:

High-Low Tone Pattern

(65) baram-baram = /ba.ram-bà.ràm/ 'parting with animsosity/disagreement'

$\mathrm{CV}_{\mathrm{i}}-\mathrm{CV}_{\mathrm{i}} \mathrm{CxCV}_{\mathrm{i}}-\mathrm{CV}_{\mathrm{i}} \mathrm{C}$

(66) gatsal-gatsal = /ga.s'al-gà.s'àl/ 'chunks of food, poorly cut'

$\mathrm{CV}_{\mathrm{i}}-\mathrm{CV}_{\mathrm{i}} \mathrm{CxCV}_{\mathrm{i}}-\mathrm{CV}_{\mathrm{i}} \mathrm{C}$

(67) tubur-tubur = /tu.bur-tù.bùr/ 'describes large and round buttocks'

$\mathrm{CV}_{\mathrm{i}}-\mathrm{CV}_{\mathrm{i}} \mathrm{CxCV}_{\mathrm{i}}-\mathrm{CV}_{\mathrm{i}} \mathrm{C}$

Low-High Tone Pattern

(68) kazar-kazar = /kà.zàr-ka.zar/ ' 'energetic nature' $\mathrm{CV}_{\mathrm{i}}-\mathrm{CV}_{\mathrm{i}} \mathrm{CxCV}_{\mathrm{i}}-\mathrm{CV}_{\mathrm{i}} \mathrm{C}$

(69) watsal-watsal = /wà.s'àl-wa.s'al/ 'wriggling' $\mathrm{CV}_{\mathrm{i}}-\mathrm{CV}_{\mathrm{i}} \mathrm{CxCV}_{\mathrm{i}}-\mathrm{CV}_{\mathrm{i}} \mathrm{C}$

(70) budum-budum = /bù.dùm-bu.dum/ 'floundering about in water or work' $\mathrm{CV}_{\mathrm{i}}-\mathrm{CV}_{\mathrm{i}} \mathrm{CxCV}_{\mathrm{i}}-\mathrm{CV}_{\mathrm{i}} \mathrm{C}$

\section{(iv) $\underline{\mathrm{CV}_{\mathrm{i}}-\mathrm{CV}_{\mathrm{i}} \times 2}$}

\footnotetext{
(1) In Sakkwatanci (Sokoto dialect), all these reduplicative ideophones with this canonical shape have HH-LF tone pattern instead of HH-LL tone pattern. (see Sambo, 2014)
} 


\section{Canonical Shape Analysis of Hausa and Bole Ideophones}

This shape contains reduplicative ideophones which have light-light syllable structure with identical short vowels. The tone pattern of these reduplicative ideophones is always $\mathrm{H}-\mathrm{H}$ (High tone on two syllables of base form and also High tone on two syllables of reduplicator). Examples:

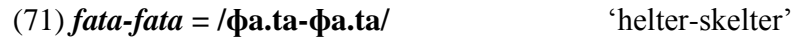

$$
\begin{aligned}
& \mathrm{CV}_{\mathrm{i}}-\mathrm{CV}_{\mathrm{i}} \mathrm{xCV}_{\mathrm{i}}-\mathrm{CV}_{\mathrm{i}} \\
& \text { (72) } \text { rugu-rugu }=/ \text { ru.gu-ru.gu/ 'shattered into pieces' } \\
& \mathrm{CV}_{\mathrm{i}}-\mathrm{CV}_{\mathrm{i}} \mathrm{xCV} \mathrm{V}_{\mathrm{i}}-\mathrm{CV}_{\mathrm{i}} \\
& \text { (73) } \boldsymbol{d u s h i - d u s h i = / d u . \int i - d u . j i / / h a z y , ~ d i m , ~ n o t ~ b r i g h t ' ~} \\
& \mathrm{CV}_{\mathrm{i}}-\mathrm{CV}_{\mathrm{i}} \mathrm{xCV} \mathrm{V}_{\mathrm{i}}-\mathrm{CV}_{\mathrm{i}}
\end{aligned}
$$

\section{(v) CVC-CVV $\times 2$}

This shape of reduplicative ideophones has heavy-heavy syllable, where first syllable is closed heavy and second syllable is open heavy. The tone pattern of these ideophones is L-H (Low on base syllables and High on reduplicator). Examples:
(74) inda-inda = /Pìn.dàa-?in.daa/ 'talking indecisively'
CVC-CVVxCVC-CVV
(75) zirga-zirga = /zìr.gàa-zir.gaa/ 'constantly going to and from'
CVC-CVVxCVC-CVV

\subsection{Analysis of Bole ideophones canonical shape}

Ideophones in Bole are not numerous as in Hausa. In this analysis we identify only 29 ideophones from Bole as our examples in descriptively analyzing canonical shapes of ideophonic words in the language. But, the syllable structures of Bole ideophones seem to be same with that of Hausa ideophones because there are consonant-final ideophones in Bole like in Hausa (which most of its ideophones are consonant-final). Below, we shall see canonical shapes of Bole ideophones base on their syllable structures.

\subsubsection{Monosyllabic}

In Bole, like in Hausa, monosyllabic ideophones have syllable structure of Onset + Nucleus $+($ Coda $)$, which stands for Consonant Vowel and Optional Coda respectively. The following are shapes of monosyllabic ideophones that we identified from Bole.

\section{(i) $\underline{\mathrm{CVC}}$}

This shape contains monosyllabic ideophones which have consonant vowel consonant. The tone pattern of these ideophones is always High. Examples:

(76) shit $=/$ /it $/ \quad$ 'modifies the colour red'

$$
\mathrm{CVC}
$$




\section{Almustapha Wali Sambo}

(77) $\operatorname{sir}=/$ sir $/ \quad$ 'modifies the colour white'

CVC

(78) sit $=/$ sit $/ \quad$ 'modifies the colour black'

CVC

(79) $\mathbf{p a u}=/$ paw $/ \quad$ 'modifies the degree of hotness'

CVC

\subsubsection{Disyllabic}

Disyllabic ideophones are those ones that have two syllable structures. In Bole, we find the following canonical shapes of disyllabic ideophones.

\section{(i) $\underline{\mathbf{C}}_{\underline{J}} \underline{\mathbf{V}}_{\underline{i}} \underline{\mathbf{C}}_{\underline{k}}-\underline{\mathbf{C}_{\mathrm{I}}} \underline{\mathbf{V}}_{\mathbf{i}} \underline{\mathbf{C}}_{\underline{k}}$}

This shape of disyllabic ideophones has heavy-heavy syllables which are also closed syllables. The two vowels of these ideophones are identical, and initial consonant of each syllable is identical to one another, likewise final consonant of each syllable. We find two different tone patterns with this shape: H-H tone pattern and L-L tone pattern. Examples:

High - High Tone Pattern

(80) shomshom $=/$ /om. . $\mathrm{om} /$ 'pointed'

$\mathrm{C}_{\mathrm{J}} \mathrm{V}_{\mathrm{i}} \mathrm{C}_{\mathrm{k}}-\mathrm{C}_{\mathrm{J}} \mathrm{V}_{\mathrm{i}} \mathrm{C}_{\mathrm{k}}$

(81) $s u l s u l=/$ sul.sul

'smooth of surface'

$\mathrm{C}_{\mathrm{J}} \mathrm{V}_{\mathrm{i}} \mathrm{C}_{\mathrm{k}}-\mathrm{C}_{\mathrm{J}} \mathrm{V}_{\mathrm{i}} \mathrm{C}_{\mathrm{k}}$

(82) golgol $=/$ gol.gol $/$

'small and round'

$\mathrm{C}_{\mathrm{J}} \mathrm{V}_{\mathrm{i}} \mathrm{C}_{\mathrm{k}}-\mathrm{C}_{\mathrm{J}} \mathrm{V}_{\mathrm{i}} \mathrm{C}_{\mathrm{k}}$

(83) shimshim $=/$ /im. $. \mathrm{im} /$

'very little'

$\mathrm{C}_{\mathrm{J}} \mathrm{V}_{\mathrm{i}} \mathrm{C}_{\mathrm{k}}-\mathrm{C}_{\mathrm{J}} \mathrm{V}_{\mathrm{i}} \mathrm{C}_{\mathrm{k}}$

(84) bilbil $=/$ bil.bil $/$

'tiny'

$\mathrm{C}_{\mathrm{J}} \mathrm{V}_{\mathrm{i}} \mathrm{C}_{\mathrm{k}}-\mathrm{C}_{\mathrm{J}} \mathrm{V}_{\mathrm{i}} \mathrm{C}_{\mathrm{k}}$

$\mathrm{C}_{\mathrm{J}} \mathrm{V}_{\mathrm{i}} \mathrm{C}_{\mathrm{k}}-\mathrm{C}_{\mathrm{J}} \mathrm{V}_{\mathrm{i}} \mathrm{C}_{\mathrm{k}}$

(86) nyomnyom $=/$ jjom.jjom $/$

'emaciated'

$$
\mathrm{C}_{\mathrm{J}} \mathrm{V}_{\mathrm{i}} \mathrm{C}_{\mathrm{k}}-\mathrm{C}_{\mathrm{J}} \mathrm{V}_{\mathrm{i}} \mathrm{C}_{\mathrm{k}}
$$

Low- Low Tone Pattern

(87) shomshom = / fòm.jòm/ 'fermented (beer, porridge, etc.)'

$\mathrm{C}_{\mathrm{J}} \mathrm{V}_{\mathrm{i}} \mathrm{C}_{\mathrm{k}}-\mathrm{C}_{\mathrm{J}} \mathrm{V}_{\mathrm{i}} \mathrm{C}_{\mathrm{k}}$

(88) nyamnyam =/jjàm.njàm/

'creating a hubbub'

$\mathrm{C}_{\mathrm{J}} \mathrm{V}_{\mathrm{i}} \mathrm{C}_{\mathrm{k}}-\mathrm{C}_{\mathrm{J}} \mathrm{V}_{\mathrm{i}} \mathrm{C}_{\mathrm{k}}$ 


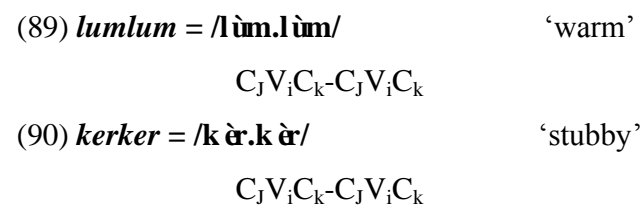

\section{(ii) CVC-CVC}

We find only two ideophones with this shape which is similar to preceded shape (i) in having closed heavy syllables, and High tone pattern. But, vowels of this shape are not identical, likewise its initial and final consonant of each syllable. Examples:

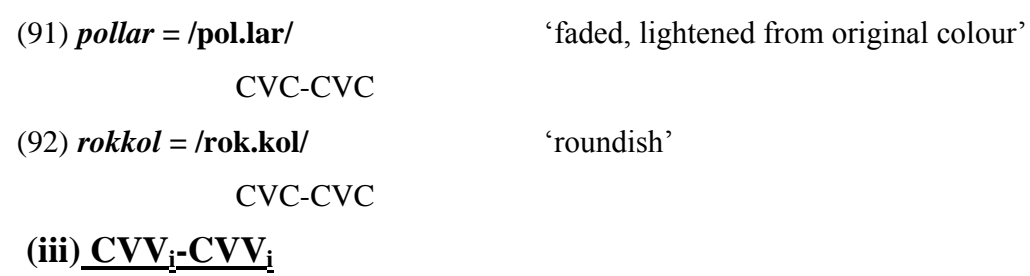

This shape is also similar to preceded shapes (i) and (ii) in having heavy first and second syllable, but this shape has first and second open heavy syllables. The vowels of this shape of ideophones are long vowels and are identical. Tone pattern of the ideophones in this shape is L-L. Examples:

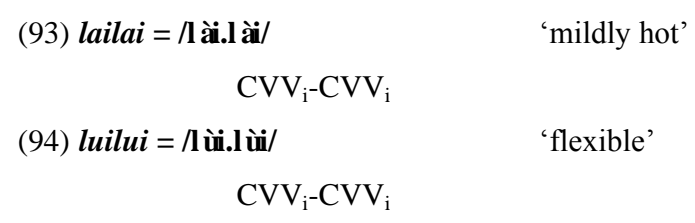

\section{(iv) $\mathrm{CV}_{\mathrm{i}}-\mathrm{CV}_{\mathrm{i}} \mathrm{C}$}

This is iambic light-heavy syllable shape that has identical vowels. The tone pattern of such ideophones with this shape is High on both first and second syllables. Examples:

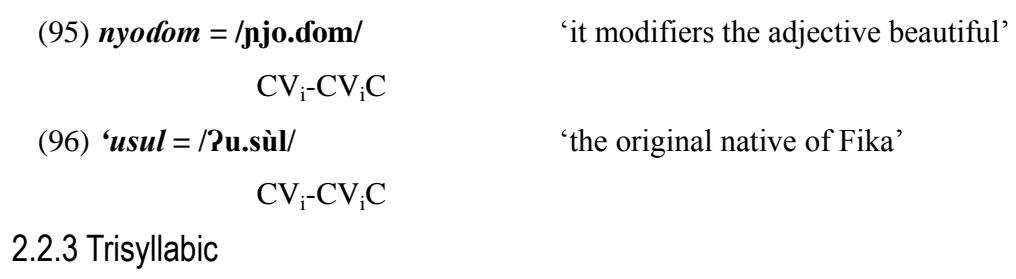

There are three canonical shapes of trisyllabic ideophones in Bole as per as this paper is concern. We have closed-open-closed syllable, closed-open-open syllable, and all open syllable structure as follows:

\section{(i) ${\underline{\mathrm{CVC}}-\mathrm{CV}_{\mathrm{i}}-\mathrm{CV}_{\mathrm{i}} \mathrm{C}}$}

This shape contains ideophones that have heavy-light-heavy syllables with identical 


\section{Almustapha Wali Sambo}

second and third vowels. They have High tone pattern. Examples:

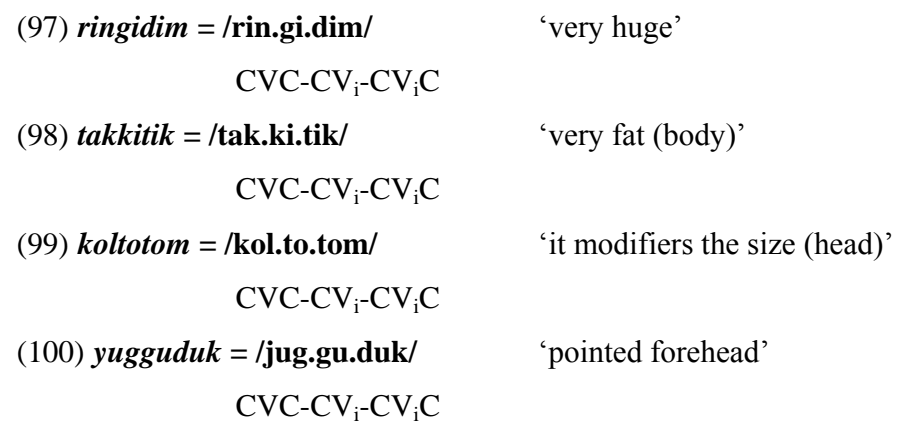

(ii) $\underline{\mathbf{C V}} \underline{\underline{C}-C_{I}} \underline{\underline{V} V_{i}-C_{I}} \underline{V} V_{i}$

This shape contains all heavy ideophones that have first closed syllable and second and third open syllables. Second and third syllables are identical (both consonants and vowels of the second and third syllables have same phonological features). The tone pattern of these ideophones is Low. Examples:

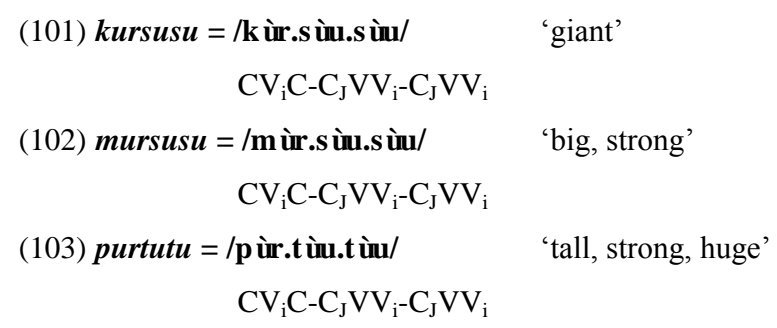

\section{(ii) $\mathrm{CVV}_{\mathbf{i}}-\mathrm{C}_{\mathrm{I}} \mathrm{VV}_{\mathrm{i}}-\mathrm{C}_{\mathrm{J}} \mathbf{V V _ { i }}$}

This is the last shape among the trisyllabic ideophones in Bole. The shape has all open-heavy syllable structure. Vowels of this shape are identical; likewise consonants of second and third syllables are also identical. Its tone pattern is High. Examples:

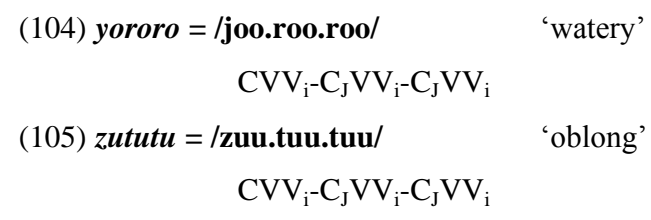

\section{Conclusion}

Ideophonic class of words is one of the lexical categories of Hausa and Bole languages. And, it is indeed, one of the controversial (grammatical) classes of both languages (though, this was not our concern in this paper). This article analyzed the syllable structures of this controversial class. And, we find out that there are many different canonical shapes of 
different syllable structures of ideophonic words from Hausa and Bole. In Hausa, we found the following canonical shapes: (monosyllabic) CVC, CVV; (disyllabic) CV-CVC, $\mathrm{CV}_{\mathrm{i}} \mathrm{C}-\mathrm{CV}_{\mathrm{i}} \mathrm{C}, \mathrm{CVV}-\mathrm{CVC}$; (trisyllabic) $\mathrm{CV}_{\mathrm{i}^{-}} \mathrm{C}_{\mathrm{J}} \mathrm{V}_{\mathrm{i}}-\mathrm{C}_{\mathrm{J}} \mathrm{V}_{\mathrm{i}}, \mathrm{CVV}_{\mathrm{i}^{-}} \mathrm{C}_{\mathrm{J}} \mathrm{VV}_{\mathrm{i}^{-}} \mathrm{C}_{\mathrm{J}} \mathrm{VV}_{\mathrm{i}}, \mathrm{CV}_{\mathrm{i}} \mathrm{C}-\mathrm{C}_{\mathrm{J}} \mathrm{V}_{\mathrm{i}} \mathrm{C}_{\mathrm{k}^{-}}$ $\mathrm{C}_{\mathrm{J}} \mathrm{V}_{\mathrm{i}} \mathrm{C}_{\mathrm{k}}$; (polysyllabic) $\mathrm{CV}_{\mathrm{i}}-\mathrm{CV}_{\mathrm{i}}-\mathrm{CV}_{\mathrm{i}} \mathrm{C}, \mathrm{CV}_{\mathrm{i}}-\mathrm{C}^{\mathrm{w}} \mathrm{V}_{\mathrm{i}}-\mathrm{CV}_{\mathrm{i}} \mathrm{C}, \mathrm{CV}_{\mathrm{i}} \mathrm{C}-\mathrm{CV}_{\mathrm{i}}-\mathrm{CVV}, \mathrm{C}_{\mathrm{J}} \mathrm{V}_{\mathrm{i}} \mathrm{C}-\mathrm{C}_{\mathrm{J}} \mathrm{V}_{\mathrm{i}} \mathrm{C}-$ $\mathrm{CVV}, \mathrm{CV}-\mathrm{CV}-\mathrm{CVV}, \mathrm{CV}_{\mathrm{i}} \mathrm{C}-\mathrm{CV}_{\mathrm{i}}-\mathrm{CV}_{\mathrm{i}}-\mathrm{C}^{\mathrm{w}} \mathrm{VV}$; (reduplicative) $\mathrm{CV}_{\mathrm{i}} \mathrm{C}-\mathrm{CV}_{\mathrm{i}} \mathrm{C}$ × $2, \mathrm{CV}-\mathrm{CVV}$ × 2 , $\mathrm{CV}_{\mathrm{i}}-\mathrm{CV}_{\mathrm{i}} \mathrm{C} \times 2, \mathrm{CV}_{\mathrm{i}}-\mathrm{CV}_{\mathrm{i}} \times 2, \mathrm{CVC}-\mathrm{CVV} \times 2$ from total number of 72 ideophones. Likewise in Bole, we found the following canonical shapes: (monosyllabic) $\mathrm{CVC}$; (disyllabic) $\mathrm{C}_{\mathrm{J}} \mathrm{V}_{\mathrm{i}} \mathrm{C}_{\mathrm{k}}-\mathrm{C}_{\mathrm{J}} \mathrm{V}_{\mathrm{i}} \mathrm{C}_{\mathrm{k}}, \mathrm{CVC}-\mathrm{CVC}, \mathrm{CVV}_{\mathrm{i}}-\mathrm{CVV}_{\mathrm{i}}, \mathrm{CV}_{\mathrm{i}}-\mathrm{CV}_{\mathrm{i}} \mathrm{C}$; (trisyllabic) CVC-CV $\mathrm{V}_{\mathrm{i}}-\mathrm{CV}_{\mathrm{i}} \mathrm{C}, \mathrm{CV}_{\mathrm{i}} \mathrm{C}-$ $\mathrm{C}_{J} \mathrm{VV}_{\mathrm{i}}-\mathrm{C}_{J} \mathrm{VV}_{\mathrm{i}}, \mathrm{CVV}_{\mathrm{i}}-\mathrm{C}_{J} \mathrm{VV}_{\mathrm{i}}-\mathrm{C}_{J} \mathrm{VV}_{\mathrm{i}}$ from 29 words of ideophone. Each among those canonical shapes has its own distinguished tone melody. One shape might have two or more different tone patterns.

Finally, this article came up with some findings of descriptive analysis of some Hausa and Bole ideophones which shed the light of their syllable structures and tone patterns. This does not mean that they are the only possible shapes from Hausa and Bole ideophones. Further research might come up with another descriptive analysis which can find out some possible shapes among Hausa and Bole ideophones.

\section{References}

Crystal, David. 2008. A Dictionary of Linguistics and Phonetics $[\mathrm{M}]\left(6^{\text {th }}\right.$ Edition). Oxford: Blackwell.

Gimba, Alhaji Maina. 2000. Bole Verb Morphology [D]. Unpublished PhD. Thesis. University of California, Los Angeles.

Newman, Paul. 1992. The Development of Falling Contours from Tone Bending in Hausa [A]. Proceedings of the Berkeley Linguistics Society [C] 18S: 128-133.

Newman, Paul. 2000. The Hausa Language: An Encyclopedic Reference Grammar [M]. New Haven: Yale University Press.

Newman, Paul. and Newman, Roxana. Ma. 1977. Modern Hausa-English Dictionary (Sabon Kamus na Hausa zuwa Turanci) [M]. Ibadan \& Zaria: University Press.

Newman, Roxana Ma. and Newman, Paul. 2001. The Hausa Lexicographic Tradition [J]. Lexikos, 2:263-286.

Sambo, Almustapha Wali. 2014. Karin Sauti A Sakkwatanci: NazarinBambance-Bambancen Karin Sauti Tsakanin Sakkwatanci da Daidaitacciyar Hausa [D]. Unpublished B.A. Dissertation. Bayero University, Kano.

Schuh, Russell and Gimba, Alhaji Maina. 2015. Bole-Hausa-English Dictionary [M]. UCLA.

Viacheslav A. Chirikba. 2008. The problem of the Caucasian Sprachbund [A]. In Pieter Muysken, (ed.). From Linguistic Areas to Areal Linguistics [C]. John Benjamins Publishing Co. 29-47.

Yalwa, Lawan Xanladi. 2002. Autosegmental Account to Some Hausa Tonal Processes [J]. Algaita Journal of Current Research in Hausa Studies, 2(1):26-46.

www.ethnologue.com/subgroups/a-15 [OL], retrieved on 13th May, 2016 at 9:30p.m. 